\title{
Host-Pathogen Interaction of Cassava (Manihot esculenta Crantz) and Cassava Mosaic Viruses (ICMV and SLCMV)
}

\author{
Raghu Duraisamy ${ }^{1}$, Chandrasekar Arumugam ${ }^{1}$, Senthil Natesan ${ }^{1}$, \\ Raveendran Muthurajan ${ }^{1}$, Karthikeyan Gandhi' ${ }^{2}$, Pugalendhi Lakshmanan ${ }^{3}$, \\ G.J. Janavi ${ }^{3}$, Nageswari Karuppusamy ${ }^{4}$ and Mohan Chokkappan ${ }^{5}$ \\ ${ }^{1}$ Centre for Plant Molecular Biology and Biotechnology, ${ }^{2}$ Centre for Plant Protection Studies, \\ ${ }^{3}$ Horticulture College and Research Institute, Tamil Nadu Agricultural University, \\ Coimbatore, India \\ ${ }^{4}$ Tapioca and Castor Research Station, Tamil Nadu Agricultural University, Yethapur, India \\ ${ }^{5}$ Central Tuber Crops Research Institute, Trivandrum, Kerala, India \\ *Corresponding author
}

\begin{tabular}{|c|c|}
\hline & A B S T R A C T \\
\hline $\begin{array}{l}\text { K e y w o r d s } \\
\text { Cassava, } \\
\text { Chlorophyll, } \\
\text { Phenol, } \\
\text { Sugars, } \\
\text { Soluble proteins, } \\
\text { Defense enzymes. }\end{array}$ & \multirow{3}{*}{$\begin{array}{l}\text { As a response of host-pathogen interaction, the induction of systemic resistance } \\
\text { (ISR) was studied in cassava upon challenge inoculation with cassava mosaic } \\
\text { viruses (ICMV and SLCMV). Due to the viral infection, the reduced amount of } \\
\text { chlorophyll a, chlorophyll b and total chlorophyll was recorded in virus infected } \\
\text { cassava seedlings compared to control (meristem derived healthy plants). The } \\
\text { accumulation of total phenol, total sugars and total soluble proteins were found to } \\
\text { be reduced in virus infected seedlings than control. Moreover, the activity of } \\
\text { defense enzymes viz., peroxidase (PO), polyphenol oxidase (PPO), phenylalanine } \\
\text { ammonia lyase (PAL) and catalase was found to be increased in infected cassava } \\
\text { seedlings compared to control. In addition an increased expression of specific } \\
\text { isoforms of PO (PO2 and PO3) and PPO (PPO2 and PPO3) were observed in } \\
\text { native PAGE analysis with response to challenge inoculation of pathogen due to } \\
\text { induced systemic resistance (ISR) induction. }\end{array}$} \\
\hline Article Info & \\
\hline $\begin{array}{l}\text { Accepted: } \\
\text { 17 June } 2017 \\
\text { Available Online: } \\
\text { 10 July } 2017\end{array}$ & \\
\hline
\end{tabular}

\section{Introduction}

Cassava, Manihot esculenta Crantz belonging to the family Euphorbiaceae, is one of the most important staple food crops (ElSharkawy, 2007; Lopez, 2005; Mann, 1997) for more than 700 million subsistence farmers in tropical and sub-tropical Africa, Asia and Latin America (IFAD and FAO, 2000) and grown widely under diverse environmental conditions. About 70 per cent of world cassava root production (which is estimated to be over $45 \mathrm{~m}$ metric tonnes of dry root annually) is used for human consumption either directly after cooking or in processed forms; the remaining 30 per cent is used for animal feed and other industrial products such as starch, glucose, and alcohol (El-Sharkawy, 2004). The major constraint in cassava production is cassava mosaic disease (CMD), 
caused by Cassava infecting geminiviruses (CIGs) belonging to the family of Geminiviridae and Genus Begomovirus, which is transmitted by whitefly, Bemisia tabaci Genn. CMD was first described in 1894. In India, this disease is caused by Indian cassava mosaic virus (ICMV) and Sri Lankan cassava mosaic virus (SLCMV) and was first noted in 1956 (Abraham, 1956), although it is likely to have occurred much earlier and the disease was described later by Alagianagalingam and Ramakrishnan (1966). It has since received considerable attention in the southern states of Kerala and Tamil Nadu, which are the main cassava growing areas of India. The infected plant stunted gradually in growth by means of reduces the plant height, petiole length, mid leaflet length and width (Thankappan and Chacko, 1976). Initially, the leaves showed faint greenish yellow specks surrounded by normal green area, which were mostly confined to the lower portion of the lamina. In fully developed diseased leaves, the chlorotic areas were yellow intermingled with normal green colour and showed mosaic mottling. In case of severe infection, the leaf gets reduced in size, misshapen, and twisted with bright yellow areas separated normally by green areas (Jos et al., 1984; Mathew, 1989).

Plants can acquire local and systemic resistance to diseases through various biological agents including necrotizing pathogens, non-pathogens (Van Loon et al., 1997). This type of resistance, known as induced systemic resistance, is mediated by triggering various defense mechanisms including production phytoalaxins, synthesis of phenolics (M'Piga et al., 1997; Chen et al., 2000), accumulation of pathogensis-related proteins (Meena et al., 2000) and deposition of structural barriers (Benhamou et al., 1996). The defense gene products peroxidases (PO) and polyphenol oxidases (PPO) catalyze the formation of lignin an phenylalanine ammonia-lyase (PAL) is involved in the synthesis of phytoalaxins and phenolics (Karthikeyan et al., 2005). The present study was carried out to compare those compounds in healthy and cassava mosaic virus infected cassava (cv. H226) plants.

In our previous report, virus free cassava plants cv. H226 were produced in vitro through apical meristems at Department of Plant Biotechnology, Centre for Plant Molecular Biology and Biotechnology, Tamil Nadu Agricultural University (Raghu et al., 2012). The virus free healthy cassava plants were confirmed by polymerase chain reaction (PCR) using geminivirus specific degenerate primers (Deng et al., 1994) and these plants were used for combined transmission of Indian cassava mosaic virus (ICMV) and Sri Lankan cassava mosaic virus (SLCMV) in cassava plants cv. $\mathrm{H} 226$ by an insect vector Bemisia tabaci (whitefly) (Raghu et al., 2012). In this study, those virus free healthy (control) and infected cassava plants cv. H226 were used to study the interaction of cassava mosaic virus with cassava through the estimation of chlorophyll, total phenol, total soluble proteins and total sugars, biochemical assay of defense enzymes including PO, PPO, PAL and catalase and native PAGE analysis of $\mathrm{PO}$ and $\mathrm{PPO}$.

\section{Materials and Methods}

Host-pathogen interaction alters the host physiology. Hence, studies were undertaken to assess changes in physiology of healthy cassava plants (meristem derived) as well as cassava mosaic virus infected cassava plant of cv. H226. General method for virus acquisition and transmission employed as described our previous report (Raghu et al., 2012). Fresh leaf samples were collected from infected and healthy cassava plants for the assay of chlorophyll, total phenol, total soluble proteins and total sugars and to assay 
the changes in activities of defense related enzymes viz., PO, PPO, PAL and catalase. Different isoforms of $\mathrm{PO}$ and PPO were analyzed through native PAGE analysis. A separate negative control was maintained without inoculation of virus.

\section{Estimation of chlorophyll}

Chlorophyll a, b, and total chlorophyll were estimated using the procedure of Witham et al., (1971). One g of leaf samples were macerated with $20 \mathrm{ml}$ of $80 \%$ acetone and the homogenate was centrifuged at $5000 \mathrm{rpm}$ for $5 \mathrm{~min}$. The supernatant was transferred to a 50 $\mathrm{ml}$ volumetric flask and the residue was again extracted with acetone till the residue became colourless. The volume of the chlorophyll extract was made up to $100 \mathrm{ml}$ with $80 \%$ acetone. The optical density was measured in a spectrophotometer at 663, 652 and $645 \mathrm{~nm}$ using 80 per cent acetone as blank. The contents of a, b and total chlorophyll were calculated using the following formulae,

$$
\begin{aligned}
& \text { Chlorophyll } \mathrm{a}=12.7(\mathrm{~A} 663)-2.69(\mathrm{~A} 645) \frac{\mathrm{V}}{1000 \times \mathrm{W}} \\
& \text { Chlorophyll } \mathrm{b}=22.9(\mathrm{~A} 645)-4.68(\mathrm{~A} 663) \frac{\mathrm{V}}{1000 \times \mathrm{W}} \\
& \text { Totalchlorophyll }=20.2(A 645)-8.02(A 663) \frac{\mathrm{V}}{1000 \times \mathrm{W}}
\end{aligned}
$$

Where,

$\mathrm{A}=$ absorbance at specific wave lengths, $\mathrm{V}=$ final volume of chlorophyll extract in $80 \%$ acetone and

$\mathrm{W}=$ fresh weight of tissue extracted.

The results were expressed as $\mathrm{mg} / \mathrm{g}$ on fresh weight basis.

\section{Estimation of total phenol}

Total phenol was estimated by adopting the protocol of Malik and Singh (1980). Leaf samples $(1 \mathrm{~g})$ were homogenized with $10 \mathrm{ml}$ of $80 \%$ and were centrifuged at $10,000 \mathrm{rpm}$ for $20 \mathrm{~min}$. The supernatant was evaporated to dryness and the residue was dissolved in known volume of water. To $1 \mathrm{ml}$ of the extract, $5 \mathrm{ml}$ of distilled water and $0.5 \mathrm{of} \mathrm{ml}$ Folin- Ciocalteau reagent were added and the solution was kept at $25^{\circ} \mathrm{C}$. After $3 \mathrm{~min}, 1 \mathrm{ml}$ of $20 \%$ sodium carbonate and $1 \mathrm{ml}$ of distilled water were added and the reaction mixture was incubated for $1 \mathrm{~h}$ at $25^{\circ} \mathrm{C}$. The intensity of blue colour was read at $650 \mathrm{~nm}$ in a spectrophotometer against a reagent blank. Catechol at different concentrations served as the standard. The amount of phenol was expressed as catechol equivalent in $\mathrm{mg} / \mathrm{g}$ of fresh tissue.

\section{Estimation of total sugars}

Total sugar content was determined by anthrone method (Hedge and Hofreiter, 1962). Leaf samples (100 mg) were homogenized with $5 \mathrm{ml}$ of $80 \%$ ethanol. The homogenate was centrifuged at $10000 \mathrm{rpm}$ for $10 \mathrm{~min}$ and the supernatant was collected. Two hundred micro litres of the supernatant was taken in a boiling tube and the alcohol was evaporated using a water bath. The residue was dissolved in $1 \mathrm{ml}$ of water. To this $4 \mathrm{ml}$ of anthrone reagent was added and heated for $8 \mathrm{~min}$ in a boiling water bath. Later, the tubes were cooled rapidly and the absorbance was read at $630 \mathrm{~nm}$ in a spectrophotometer. Dglucose was used as a standard and the total sugar content was expressed in terms of $\mathrm{mg}$ of 
glucose equivalent per $\mathrm{g}$ of leaf tissue on fresh weight.

\section{Estimation of total soluble proteins}

Total soluble protein content was estimated as described by Bradford (1976). Preparation of stock solution: Coomassie brilliant blue G250 (100 mg) was dissolved in $50 \mathrm{ml}$ of $95 \%$ ethanol and to that $100 \mathrm{ml}$ of concentrated ortho-phosphoric acid was added. The volume was made up to $200 \mathrm{ml}$ with water and kept at $4^{\circ} \mathrm{C}$. Stock solution was diluted four times with water to get the working solution. Sample preparation: Leaf samples $(1 \mathrm{~g})$ were homogenized in $5 \mathrm{ml}$ of $0.1 \mathrm{M}$ phosphate buffer ( $\mathrm{pH}$ 7.0). The homogenate was centrifuged at $10000 \mathrm{rpm}$ for $10 \mathrm{~min}$ at $4^{\circ} \mathrm{C}$ and the supernatant was used for the assay of soluble protein. Assay: To $0.5 \mathrm{ml}$ of the extract, $0.5 \mathrm{ml}$ of water and $2.5 \mathrm{ml}$ of the working dye solution were added and incubated for five min at room temperature. One $\mathrm{ml}$ of water added with $2.5 \mathrm{ml}$ of dye served as the blank. The intensity of blue colour was measured at $595 \mathrm{~nm}$ in a spectrophotometer. Bovine serum albumin at various concentrations served as the protein standard. Soluble protein content was expressed as mg albumin equivalent of soluble protein per $g$ on fresh weight basis.

\section{Peroxidase (PO)}

Leaf sample (1 g) was homogenized with 1 $\mathrm{ml}$ of $0.1 \mathrm{M}$ phosphate buffer $\mathrm{pH} 7.0$ and was centrifuged at $10000 \mathrm{rpm}$ for $20 \mathrm{~min}$ at $48^{\circ} \mathrm{C}$. The supernatant was used to assay activities of PO and PPO and catalase. The activity of peroxidase was determined as detailed by Hammerschmidt et al., (1982). The reaction mixture consisting of $1.5 \mathrm{ml}$ of $0.05 \mathrm{M}$ pyrogallol and $0.1 \mathrm{ml}$ of enzyme extract was taken in a cuvette. To initiate the reaction 0.5 $\mathrm{ml}$ of $1 \% \mathrm{H}_{2} \mathrm{O}_{2}$ was added. The change in absorbance was recorded at $420 \mathrm{~nm}$ at $30 \mathrm{~s}$ interval for $3 \mathrm{~min}$ from zero $\mathrm{s}$ of incubation at room temperature. The boiled enzyme served as blank. The enzyme activity was expressed as change in absorbance/min/g of fresh tissue.

\section{Polyphenol oxidase (PPO)}

The reaction mixture consisting of $1.5 \mathrm{ml}$ of $0.1 \mathrm{M}$ sodium phosphate $(\mathrm{pH} 7.0)$ and $0.1 \mathrm{ml}$ of enzyme extract was taken in a cuvette. To this, $0.2 \mathrm{ml}$ of catechol $(0.01 \mathrm{M})$ was added to initiate the reaction. The change in absorbance was recorded at $495 \mathrm{~nm}$ at $30 \mathrm{~s}$ interval for three min and the results were expressed as change in absorbance $\min ^{-1} \mathrm{~g}^{-1}$ of fresh tissue (Mayer et al., 1965).

\section{Catalase}

Catalase activity was assayed in the leaf samples collected from healthy and infected cassava plants as per the method described by Beers and Sizer (1952). Reaction mixture consisting of $0.5 \mathrm{ml}$ of $0.1 \mathrm{M}$ phosphate buffer (pH 7.0), $0.2 \mathrm{ml}$ of enzyme extract and $0.1 \mathrm{ml}$ of $1 \% \mathrm{H}_{2} \mathrm{O}_{2}$ was incubated at $28 \pm 1^{\circ} \mathrm{C}$. At the start of the enzyme reaction the absorbance of the mixture was set zero at $230 \mathrm{~nm}$ in a spectrophotometer and changes in the absorbance was recorded at $15 \mathrm{sec}$ interval for 3 min. Catalase activity was expressed as change in the absorbance of the reaction mixture/ $\mathrm{min} / \mathrm{g}$ of leaf tissue on fresh weight basis.

\section{Phenylalanine ammonia lyase (PAL)}

Leaf samples $(500 \mathrm{mg}$ ) were homogenized in $5 \mathrm{ml}$ of cold $25 \mathrm{mM}$ borate $\mathrm{HCl}$ buffer $(\mathrm{pH}$ 8.8). The homogenate was centrifuged at $10000 \mathrm{rpm}$ for $15 \mathrm{~min}$ and the supernatant was used as enzyme source. The assay mixture consisted of $0.2 \mathrm{ml}$ of enzyme extract, $1.3 \mathrm{ml}$ water and $0.5 \mathrm{ml}$ borate buffer. The reaction was initiated by the addition of $1 \mathrm{ml}$ of $12 \mathrm{mM}$ L-phenylalanine. The reaction mixture was incubated for $1 \mathrm{~h}$ at $32^{\circ} \mathrm{C}$. The reaction was stopped by the addition of $0.5 \mathrm{ml}$ of $2 \mathrm{~N} \mathrm{HCl}$. 
The absorbance was measured at $290 \mathrm{~nm}$. PAL activity was determined as the rate of conversion of L-phenylalanine to transcinnamic acid. The enzyme activity was expressed as $\mathrm{n}$ mol of trans-cinnamic $\mathrm{acid} / \mathrm{min} / \mathrm{g}$ of leaf tissue (Dickerson et al., 1984).

\section{Native-polyacrylamide gel electrophoresis (PAGE) analysis}

The isoforms profile of $\mathrm{PO}$ and $\mathrm{PPO}$ were examined by discontinuous native polyacrylamide gel electrophoresis (nativePAGE) (Laemmli, 1970). Samples collected from healthy meristem derived and cassava mosaic virus infected plants were homogenized with $1 \mathrm{ml}$ of $0.1 \mathrm{M}$ sodium phosphate buffer $\mathrm{pH} 7.0$ and centrifuged at $10000 \mathrm{rpm}$ for $20 \mathrm{~min}$ at $4^{\circ} \mathrm{C}$. The protein content of the sample was determined by the Bradford (1976) method. Samples (50 $\mu \mathrm{g}$ protein) were loaded onto separating gel of $8 \%$ and stacking gel of 4\% polyacrylamide concentration (Sigma, USA) for the analysis to find out the expression of $\mathrm{PO}$ and $\mathrm{PPO}$ isoforms. After electrophoresis, the gel was stained in $0.2 \mathrm{M}$ acetate buffer at $\mathrm{pH} 4.2$ containing $0.05 \%$ benzidine for $30 \mathrm{~min}$ in the dark. Then drops of $\mathrm{H}_{2} \mathrm{O}_{2}(0.03 \%)$ were added slowly with constant shaking to visualize the PO isoforms. After staining the gel was washed with distilled water (Nadlony and Sequerira, 1980). For assessing PPO isoforms profile, the gels were equilibrated for $30 \mathrm{~min}$ in $0.1 \%$ p-phenylene diamine in $0.1 \mathrm{M}$ potassium phosphate buffer ( $\mathrm{pH}$ 7.0) followed by addition of $10 \mathrm{mM}$ catechol in the same buffer and kept in a shaker with gentle shaking. The appearance of dark brown protein bands was noticed after some time (Jayaraman et al., 1987).

\section{Results and Discussion}

Estimation of chlorophyll: Meristem derived healthy cassava plants of cv. H226 were having more chlorophyll content. Chlorophyll a, b and total chlorophyll were significantly more in healthy cassava plants than in ICMV and SLCMV infected cassava plants. Such increase in healthy plants over infected was 18.38 per cent in chlorophyll a, 27.99 per cent in chlorophyll b and 24.13 per cent in total chlorophylls (Table 1 and Figure 1a). Estimation of total phenols: Meristem derived healthy cassava plants of cv. H226 exhibited 32.24 per cent increase in accumulation of total phenol as compared to that in Cassava mosaic virus infected plants (Table 2 and Figure 1b). Estimation of total sugars: Meristem derived healthy cassava plants of cv. H226 exhibited a significant increase in total sugar content ( 26.43 per cent) as compared to that in Cassava mosaic virus infected plants (Table 2 and Figure 1b). Estimation of total soluble proteins: Total soluble proteins in meristem derived healthy cassava plants of cv. H226 increased to the tune of 33.91 per cent as compared to that in Cassava mosaic virus infected plants (Table 2 and Figure 1b).

Peroxidase $(P O)$ : Infection of the cassava plants (cv. H226) by cassava mosaic virus led to increased peroxidase activity (Table 3 ). When compared to Cassava mosaic virus infected cassava plants peroxidase activity significantly decreased in meristem derived healthy cassava plants of cv. H226 (Figure 1c) to the tune of 23.55 per cent. Polyphenol oxidase (PPO): Data presented in table 3 revealed that the effect of virus infection on Polyphenol oxidase activity, which is a defence related enzyme. Infection of the cassava plants (cv. H226) by cassava mosaic virus led to increased Poly phenol oxidase activity. The activity of the enzyme was found to be significantly less in meristem derived healthy cassava plants of cv. H226 (Figure 1c) to the tune of 33.28 per cent as compared to that in infected plant. Catalase: When compared to meristem derived healthy cassava plants, activity of catalase was increased in infected plants and less in healthy plants. The percentage decrease of catalase 
activity in healthy cassava plants of cv. H226 was 23.52 per cent (Figure 1c and Table 3). Phenylalanine ammonia lyase (PAL): Data presented in table 3 indicated an increased activity of PAL in Cassava mosaic virus infected plants. The activity of the enzyme significantly decreased in meristem derived healthy cassava plants of cv. H226 (Figure 1d) to the tune of 11.67 per cent as compared to that in infected plant.

\section{Native PAGE analysis of PO and PPO isoforms in meristem derived and Cassava mosaic virus infected cassava plants of $\mathrm{cv}$. H226}

Native PAGE analysis revealed the presence of four PO (PO1, PO2, PO3 and PO4) and four PPO (PPO1, PPO2, PPO3 and PPO4) isoforms in cassava mosaic virus infected and meristem derived cassava plants of cv. H226 whereas, two PO (PO1 and PO4) and two PPO (PPO1 and PPO4) isoforms were present in meristem derived cv. H226 cassava plants. Two PO (PO2 and PO3) and two PPO (PPO1 and PPO3) isoforms were found in CMD infected cv. H226 cassava plants (Figure 2).

Plant virus infection leads to measurable changes in the physiological process of the host. Any biochemical or physiological study on infected plants may contribute to understand the virus disease (Bawden and Pirie, 1952). Porter (1959) reported that changes in metabolism of host cell induced by the virus leads to various macroscopic and microscopic symptoms. To measure these changes the CMD infected plants will compared with a completely virus free plantlets derived from meristem culture. The present study gives direct evidence on the induction of plant defense mechanism in the control of cassava mosaic disease caused by cassava mosaic virus. Induction of systemic resistance has been established as a new mechanism by which plants defend themselves against pathogen attack (Van Loon et al., 1998). There are various reports confirm the induction of systemic resistance (Yedidia et al., 1999; Meena et al., 2000).

As a response of induction of systemic resistance (ISR), accumulation of reactive oxygen species (ROS) is central to plant response to several pathogens. One of the sources of ROS is the chloroplast because of the photoactive nature of the chlorophylls. Chlorophyllase I, induced after tissue damage caused by cassava mosaic virus, is degrade the chlorophyll molecules. In the present study, Chlorophyll a, b and total chlorophyll were significantly more in meristem derived healthy cassava plants than in cassava mosaic virus infected cassava plant. This is in agreement with the results of Alagianagalingam and Ramakrishnan (1978). They reported that mosaic infected cassava leaves had less chlorophyll and carotene and lower photosynthetic rate. Similar results were obtained by Vasanthi (1998). The loss in chlorophyll content might be due to the diversion of plastid protein into virus protein (Bawden and Pirie, 1952) or a result of normal cell degrading enzymes that utilize chlorophyll as a substrate (Goodman et al., 1977). This has also been attributed to either the inhibition of chloroplast development or the distribution of pigments in matured chloroplasts (Matthews, 1981). In meristem derived plants because of the absence of the virus there was no degradation of chlorophyll.

The results revealed a significant increase in total sugars in the meristem culture derived healthy cassava plants of cv. H226 (26.43 per cent), whereas significant reduction in total sugar content was observed in cassava mosaic virus infected plants. The reduced levels of total sugar content of the diseased plants may be due to higher utilization of sugars for phosphate ester formation required for virus nucleic acid synthesis (Singh and Srivastava, 
1974). Conversion of sugars into amino acids and organic acids may be yet another possible reason for the reduced level of sugars in virus infected plant (Maggyaarosy et al., 1973). In meristem derived plants because of the absence of the virus there was no chance of conversion of sugars into amino acids and organic acids.

The total soluble protein content was significantly increased in meristem derived healthy cassava plants of cv. H226, whereas in diseased plant total soluble protein content was decreased. This is in contrary with the findings of Nambisan (1994), Vasanthi (1998) and Madhubala (2003). Where they reported that total soluble protein content was significantly increased in cassava mosaic virus infected cassava plants.

The phenolic compounds as constituents of lignin may contribute to enhance the mechanical strength of the host cell wall and may also inhibit pathogen growth as they are fungitoxic in nature. The induction of phenols might be due to the activation of the shikimic acid pathway, through which the aromatic amino acids phenylalanine and tyrosine are formed and channelled for the synthesis of phenolics (M'Pign et al., 1997). The present investigation revealed that total phenol content was more in meristem derived healthy cassava plants, whereas total phenol content was less in cassava mosaic virus infected cassava plants of cv. H226. This finding is in contrary with the observations of Vasanthi (1998) and Madhubala (2003), where they reported that total phenol content was more in cassava mosaic virus infected cassava plants. In general phenols are mainly responsible for resistance in plants against stresses. Similar kind of findings was reported for blackgram against dry root rot (Sundaravadana, 2002) and groundnut against $C$. Personatum (Meena et al., 2000). The result of the present study revealed that the virus infection in cassava plants (cv. H226) led to increase in PO, PPO, PAL and catalase activity. This is in agreement with the findings of Alagianagalingam and Ramakrishnan (1974), Vasanthi (1998) and Madhubala (2003). They noticed significant differences in PO, PPO, PAL and catalase activity in the infected plants. PO is an early response in plants to pathogen attack and plays a key enzyme in the biosynthesis of lignin which limits the extent of pathogen spread (Bruce and west, 1989), It also catalyses the oxidation of phenols to quinines which are highly fungitoxic. The product of this enzymes in the presence of a hydrogen donor and hydrogen peroxide have antimicrobial activity and even antiviral activity (Van Loon and Callow, 1983) increase activity of cell wall bound PO have been elicited in deferent plants such as cucumber (Chen et al., 2000) and tobacco (Ahl Goy et al., 1992) due to pathogen infection. In bean, rhizosphere colonization by various bacteria induced PO activity (Zolor and Anderson, 1992). In the present study, a rapid increase in PO activity was recorded in cassava infected with cassava mosaic virus. The present study also indicates that expression four PO isoforms, PO1, PO2, PO3 and PO4 was more prominent in cassava plants infected with cassava mosaic virus. Moreover, the isoforms PO2 and PO3 were expressed only in the infected plants rather than healthy.

PAL is the first enzyme in the phenyl propanoid metabolism and has a definite role in defense mechanism of plants (Friend and Threshfall, 1976). It plays an important role in the biosynthesis of various defense chemicals in phenylpropanoid metabolism. Activity of PAL could be induced in plant-pathogen interaction (De Mayer et al., 1999). Several studies have shown that PAL activity is induced in plants upon infection (Chen et al., 2000; Sundaravadana, 2002; Saravanakumar, 2003). 
Table.1 Estimation of chlorophyll content in meristem derived and cassava mosaic virus infected cassava plants (cv. H226)

\begin{tabular}{|c|c|c|c|c|c|c|}
\hline Treatments & $\begin{array}{l}\text { Chlorophyll a* } \\
\text { (mg/g of fresh } \\
\text { weight) }\end{array}$ & $\begin{array}{l}\text { Decrease over } \\
\text { infected }(\%)\end{array}$ & $\begin{array}{l}\text { Chlorophyll b* } \\
\text { (mg/g of fresh weight) }\end{array}$ & $\begin{array}{l}\text { Decrease over } \\
\text { infected }(\%)\end{array}$ & $\begin{array}{l}\text { Total Chlorophyll * } \\
\text { (mg/g of fresh weight) }\end{array}$ & $\begin{array}{l}\text { Decrease over } \\
\text { infected }(\%)\end{array}$ \\
\hline & $($ Mean \pm SE $)$ & $($ Mean \pm SE) & $($ Mean \pm SE) & $($ Mean \pm SE) & $($ Mean \pm SE) & $($ Mean \pm SE) \\
\hline Control & $0.979 \pm 0.015$ & - & $0.567 \pm 0.000$ & & $1.785 \pm 0.020$ & 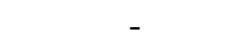 \\
\hline Infected & $0.827 \pm 0.009$ & $18.38 \pm 0.002$ & $0.443 \pm 0.005$ & $27.99 \pm 0.192$ & $1.438 \pm 0.031$ & $24.13 \pm 0.739$ \\
\hline
\end{tabular}

$*$ Mean of five replications

Table.2 Estimation of total phenol, total sugars and total soluble proteins contents of meristem derived and cassava mosaic virus infected cassava plants (cv. H226)

\begin{tabular}{|c|c|c|c|c|c|c|}
\hline Treatments & $\begin{array}{l}\text { Total phenols* } \\
\text { (mg/g of fresh } \\
\text { weight) }\end{array}$ & $\begin{array}{l}\text { Decrease over } \\
\text { infected }(\%)\end{array}$ & $\begin{array}{l}\text { Total sugars* } \\
\text { (mg D-glucose } \\
\text { equivalent/g of } \\
\text { fresh weight) }\end{array}$ & $\begin{array}{l}\text { Decrease over } \\
\text { infected }(\%)\end{array}$ & $\begin{array}{l}\text { Total soluble } \\
\text { proteins* }(\mathrm{mg} / \mathrm{g} \\
\text { fresh weight) }\end{array}$ & $\begin{array}{l}\text { Decrease over } \\
\text { infected }(\%)\end{array}$ \\
\hline & $($ Mean \pm SE) & $($ Mean \pm SE) & $($ Mean $\pm \mathrm{SE})$ & $($ Mean \pm SE $)$ & $($ Mean \pm SE) & $($ Mean \pm SE) \\
\hline Control & $1.415 \pm 0.032$ & - & $11.736 \pm 0.345$ & - & $1.011 \pm 0.008$ & - \\
\hline Infected & $1.07 \pm 0.009$ & $32.24 \pm 0.314$ & $9.283 \pm 0.244$ & $26.43 \pm 0.809$ & $0.755 \pm 0.005$ & $33.91 \pm 0.509$ \\
\hline
\end{tabular}

Table.3 Defense enzyme status in meristem derived and cassava mosaic virus infected cassava plants (cv. H226)

\begin{tabular}{|c|c|c|c|c|c|c|c|c|}
\hline Treatments & $\begin{array}{l}\text { PO activity* } \\
\text { (Change in } \\
\text { abs/min } / g \text { ) }\end{array}$ & $\begin{array}{l}\text { Increase over } \\
\text { control }(\%)\end{array}$ & $\begin{array}{l}\text { PPO activity* } \\
\text { (Change in } \\
\text { abs/min/g) }\end{array}$ & $\begin{array}{l}\text { Increase over } \\
\text { control }(\%)\end{array}$ & $\begin{array}{l}\text { PAL activity* } \\
\text { ( } \mathrm{n} \text { moles of } \\
\text { transcinnamic acid/g) }\end{array}$ & $\begin{array}{l}\text { Increase over } \\
\text { control }(\%)\end{array}$ & Catalase* & $\begin{array}{l}\text { Increase over } \\
\text { control }(\%)\end{array}$ \\
\hline & $($ Mean \pm SE $)$ & $($ Mean \pm SE $)$ & $($ Mean \pm SE $)$ & $($ Mean \pm SE $)$ & $($ Mean \pm SE $)$ & $($ Mean \pm SE $)$ & $($ Mean \pm SE) & $($ Mean \pm SE) \\
\hline Control & $0.74 \pm 0.006$ & - & $0.397 \pm 0.002$ & & $106 \pm 3.114$ & 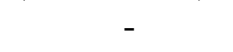 & $0.608 \pm 0.001$ & 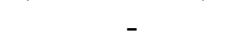 \\
\hline Infected & $0.968 \pm 0.005$ & $23.55 \pm 0.250$ & $0.595 \pm 0.014$ & $33.28 \pm 0.624$ & $120 \pm 1.110$ & $11.67 \pm 0.129$ & $0.795 \pm 0.003$ & $23.52 \pm 0.328$ \\
\hline
\end{tabular}

$*$ Mean of five replications 
Fig.1 Biochemical assays between control (black colour bars) and infected (ash colour bars) cassava plants challenged with the pathogen cassava mosaic virus: (a) induction of chlorophyll a,b and total chlorophyll; (b) induction of total phenol, total sugars and total soluble proteins; (c) changes in the activities of peroxidase (PO) and polyphenol oxidase (PPO); (d) n moles of transcinnamic acid/g of phenylalanine ammonia lyase; (e) Catalase

(a)

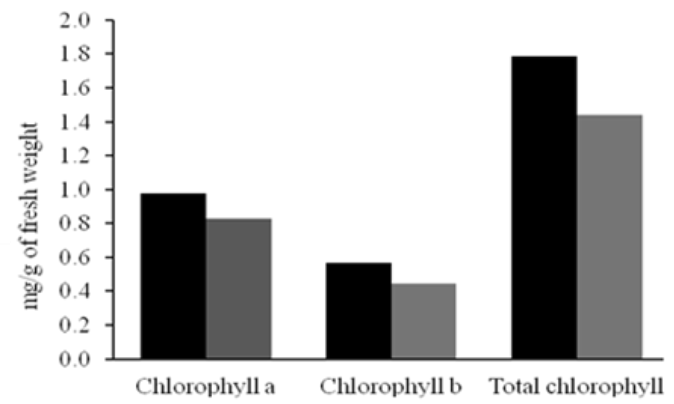

(b)

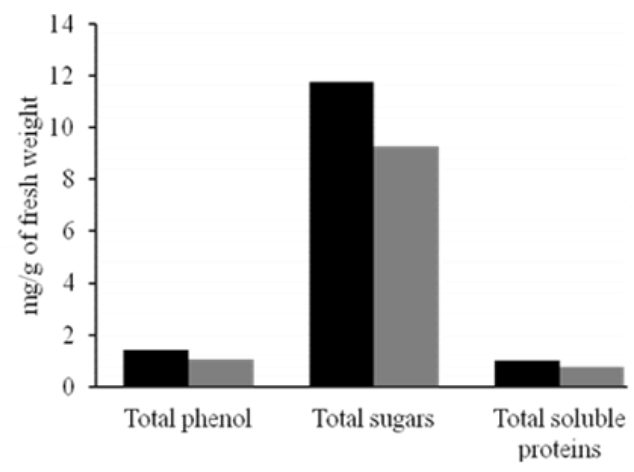

(c)

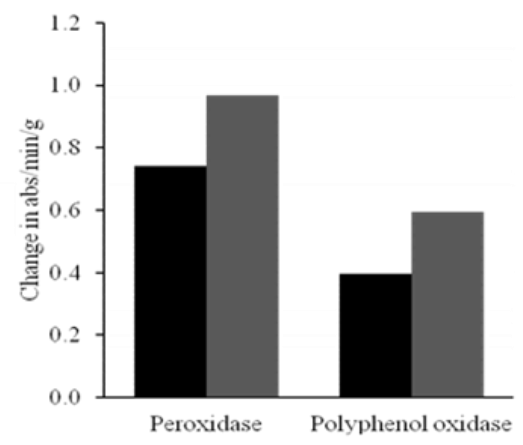

(d)

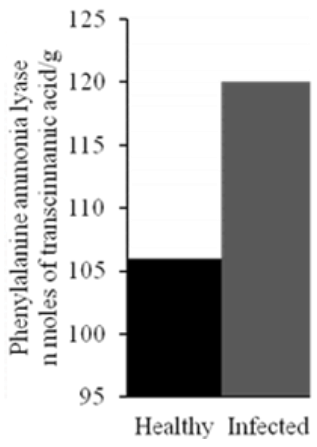

(e)

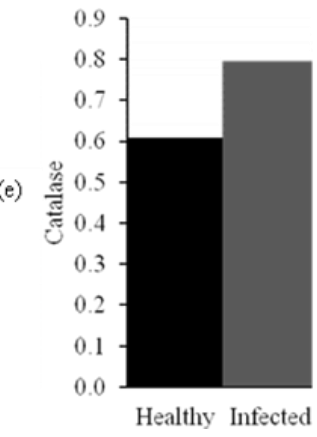

Fig.2 Native PAGE analysis of defense related enzyme induced in cassava cv. H226 challenged with or without the pathogen cassava mosaic virus: (a) peroxides (PO) isoforms profile; (b) polyphenol oxidase (PPO) isoforms profile. Lane 1and 2 is control plants; Lane 3 and 4 is infected plants

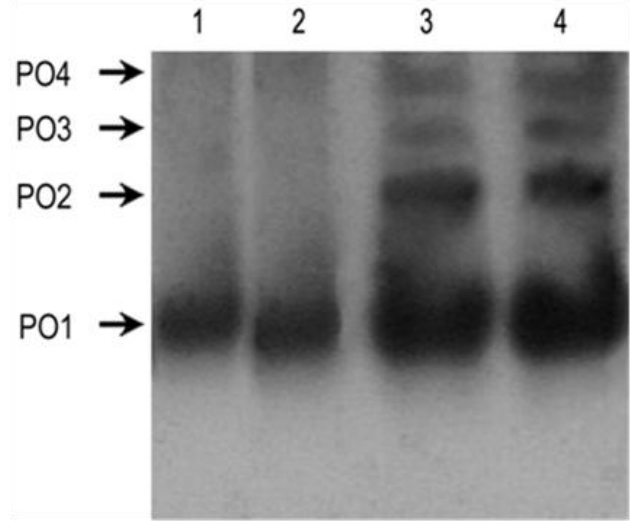

(a)

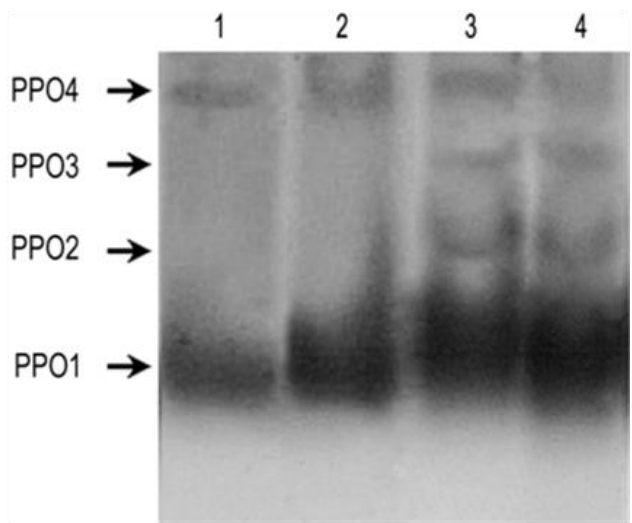

(b) 
PPO catalyses the oxidative phenolic compounds and plays major role in defense. Similar to other enzymes, PPO activity also increased by infection with cassava mosaic virus, expression of four PPO isoforms, PPO1, PPO2, PPO3 and PPO4 was very clear in cassava infected with cassava mosaic virus. The induced PPO2 and PPO3 isoforms and a higher level of expression of the other isoforms were implicated in induced defense responses against cassava mosaic virus in cassava. The virus infected plant accelerates the synthesis of catalase to remove excess hydrogen peroxide produced due to increased respiration (Lodh et al., 1973). The abrupt rise in the enzyme activity may be due to alteration in redox potential of the host as a result of virus infection (Vidhayasekaran, 1995). Since the meristem derived plants are free from the virus infection there was no induction of the above mentioned enzymes.

Induced systemic resistance is an important mechanism of bio-control that received considerable attention in recent times. Pathogenesis-related (PR) proteins, isoenzymes (different molecular form of same enzyme specificity) of phenylproponoid metabolism including Peroxidase (PO) and Polyphenol oxidase (PPO) that catalyze the formation of lignin and phenyl ammonialyase (PAL) that involves in phytoalexin and phenolics biosynthesis are found to be associated with induced systemic resistance to some plant pathogens (Shannon, 1968). In the present study four different isoforms of both PO and PPO were noticed during hostpathogen interaction between cassava and cassava mosaic virus.

\section{Acknowledgements}

The authors would like to thank Rajiv Gandhi National Fellowship (RGNF) grant (No: F. 14-2 (SC)/2008 (SA-III) Dt: 14.09.2009) to Mr. D. Raghu from the University Grant
Commission (UGC), New Delhi, India for financial support. We express our sincere thanks to The Professor and Head for providing cassava setts of cv. H226 maintained at Tapioca and Castor Research Station (TCRS), Yethapur at Salem in Tamil Nadu. We are also grateful to the Professor and Head, Department of Fruit Science, Faculty of Horticulture, Tamil Nadu Agricultural University (TNAU) for providing the PTC laboratory facilities to produces virus free healthy meristem derived cassava plants.

\section{References}

Abraham, A. 1956. Tapioca cultivation in India. Farm Bulletin, Indian Council of Agricultural Research (ICAR), New Delhi. 17: 20.

Ahl Goy, P., Felix, G., Metraux, J.P. and Meins, J.R. 1992. Resistance to disease in the hybrid Nicotiana glutinosa $\times$ Nicotiana debneyi is associated with high constitutive levels of $\beta$-1,3glucanase, chitinase, peroxidase and polyphenol oxidase. Physiol. Mol. Plant Pathol., 41: 11-21.

Alagianagalingam, M.N. and Ramakrishnan, K. 1996. Cassava mosaic disease in India. South Indian Horticulture, 14: 71-72.

Alagianagalingam, M.N. and Ramakrishnan, K. 1974. Effect of Cassava mosaic virus in the nitrogen metabolism of cassava (Manihot esculenta Crantz.). Madras Agri. J., 61: 18-26.

Alagianagalingam, M.N. and Ramakrishnan, K. 1978. Effect of Cassava mosaic virus on photosynthetic pigments and photosynthesis. Auara, 718: 120-123.

Bawden, F.C. and Pirie, N.W. 1952. Physiology of virus diseases. Annu. Rev. Plant Physiol., 3: 171-178.

Beers, R.F. and Sizer, I.W. 1952. A spectrometric method for measuring the 
breakdown of hydrogen peroxide and catalase. J. Biol. Chem., 195: 133-140.

Benhamou, N., Kloepper, J.W., QuadtHallman, A. and Tuzun, S. 1996. Induction of defense-related ultrastuctural modifications in pea root tissues inoculated with endophytic bacteria. Plant Physiol., 112: 919-929.

Bradford, M.M. 1976. A rapid and sensitive method for the quantification of microgram of proteins using the principles of protein-dye binding. Anal. Biochem., 72: 248-254.

Bruce, R.J., West, C.A. 1989. Elicitation of lignin biosynthesis and isoperoxidase activity by pectic fragments in suspension cultures caster bean. Plant Physiol., 91: 889-897.

Chen, C., Belanger, R.R., Benhamou, N. and Paulitz, T. 2000. Defense enzymes induced in cucumber roots by treatment with pant growth promoting rhizobacteria (PGPR) and Pythium aphanidermatum. Physiol. Mol. Plant Pathol., 56: 13-23.

De Meyer, G., Capieau, K., Audenaert, K., Buchala, A., Metraux, J.P. and Höfte M. 1999. Nanogram amounts of salicylic acid produced by the rhizobacterium Pseudomonas aeruginosa 7NSK2 activate the systemic acquired resistance pathway in bean. Mol. Plant- Microbe Interact., 12: 450-458.

Deng, D., McGrath, P.F., Robinson, D.J. and Harrison, B.D. 1994. Detection and differentiation of whitefly-transmitted geminiviruses in plants and vector insects by the polymerase reaction with degenerate primers. Ann. Appl. Biol., 125: 327-336.

Dickerson, D.P., Pascholati, S.F., Hagerman, A.E., Butler, L.G. and Nicholson, R.L. 1984. Phenylalanine ammonia-lyase and hydroxyl cinnamate CoA ligase in maize mesocotyls inoculated with Helminthosporium maydis or $H$. carbonum. Physiol. Plant. Pathol., 25: 111-123.

El-Sharkawy, M.A. 2004. Cassava biology and physiology. Plant Mol. Biol., 56(4): 481-501.

El-Sharkawy, M.A. 2007. Physiological characteristics of cassava tolerance to prolonged drought in the tropics: Implications for breeding cultivars adapted to seasonally dry and semiarid environments. Braz. J. Plant Physiol., 19(4): 257-286.

Friend, J. and Threshfall, A. 1976. Induction of defense enzymes in plants due to pest and disease attack. In: Biochemical aspects of plant parasitic relationship. Academic Press, London. pp. 354.

Goodman, R.M., Bird, J. and Thongmeearkom, P. 1977. An unusual virus like particles associated with golden yellow mosaic of beans. Phytopathol., 67: 37-42.

Hammerschmidt, R., Nuckles, E. M. and Kuc, J. 1982. Association of enhanced peroxidase activity with induced systemic resistance of cucumber to Colletotrichum lagenarium. Physiol. Plant Pathol., 20: 73-82.

Hedge, J.E. and Hofreiter, B.T. 1962. Estimation of total sugars. In: Methods in Carbohydrate Chemistry, (Eds.) Whistler, R.L. and Bemiller, J.N. Vol. 17. Academic press, New York.

Hoagland, D.R. and Arnon, D.I. 1950. The water-culture method for growing plants without soil. Circ. 347. Univ. of Calif. Agric. Exp. Station, Berkley.

IFAD and FAO. 2000. Cassava Can Play a Key Role in Reducing Hunger and Poverty, Press Release 00/25, Rome.

Jayaraman, K.S., Ramanuja, M.N., Vijayaraghavan, P.K. and Vaidyanathan, C.S. 1987. Oxidative enzyme in pearl millet. Food Chem., 24: 203.

Jos, J.S., Bai, K.V. and Nair, N.G. 1984. 
Unreported symptoms associated with mosaic disease in cassava. Indian Phytopathology. 37: 696-699.

Karthikeyan, M., Jayakumar, V., Tadhika, K., Bhaskaran, R., Velazhahan, R. and Alice, D. 2005. Induction of resistance in host against the infection of leatf blight pathogen (Alternaria palandui) in onion (Allium cepa var aggricatum). Indian J. Biochem. Biophys., 42: 371377.

Laemmli, U.K. 1970. Cleavage in structural proteins during the assembly of head of bacteriophage $\mathrm{T}_{4}$. Nature, 227: 680-685.

Lodh, S.B., Selvaraj, Y. and Divakar, N.G. 1973. Changes in pigments, oxidative and cellulolytic enzymes in tomato (Lycopersicon esculentum Mill.) infected with tomato leaf curl virus. Indian J. Exp. Biol., 9: 281-283.

Lopez, C., Piegu, B., Cooke, R., Delsen, M., Tohme, J. and Verdier, V. 2005. Using cDNA and genomic sequences as tools to develop SNP strategies in cassava (Manihot esculenta Crantz). Theor. Appl. Genet., 110: 425-431.

M'Piga, P., Belanger, R.R., Paulitz, T.C. and Benhamou, N. 1997. Increased resistance to Fusarium ozysporum f.sp. radicis-lycopersici in tomato plants treated with endophytic bacterium Pseudomonas fluorescens strain 63-28. Phsiol. Mol. Plant Pathol., 50: 301-320.

Madhubala, T. 2003. Elimination of Indian Cassava mosaic virus (ICMV) from cassava (Manihot esculenta crantz.) and study on physiology of the diseased plants. M.Sc Thesis, Tamil Nadu Agricultural University, Coimbatore, India.

Maggyaarosy, A.C., Buchanan, B.B. and Schurmann, P. 1973. Effect of systemic virus infection on chloroplast function and structure. Virol., 55: 426-438.

Malik, C.P. and Singh, M.B. 1980. Estimation of total phenols in plants. In: Plant
Enzymology and Histo Enzymology. Kalyani Publishers, New Delhi. pp. 286.

Mann, C. 1997. Reseeding the green revolution. Sci., 277: 1038-1043.

Mathew, A.V. 1989. Studies on Indian Cassava mosaic virus diseases. PhD Thesis, University of Agricultural Sciences, Bangalore, India. pp. 237.

Matthews, R.E.F. 1981. Physiology of virus infection in plants. In: Plant Virology. Academic press Inc., New York. pp. 897.

Mayer, A.M., Harel, H. and Shaul, R.B. 1965. Assay of catechol oxidase, a critical comparison of methods. Phytochem., 5: 783-789.

Meena, B., Radhajeyalakshmi, R., Marimuthu, T., Vidhyasekaran, P., Doraiswamy, S. and Velazhahan, R. 2000. Induction of pathogenesis-relate proteins, phenolics and phenylalanine ammonia-lyase in groundnut by Pseudomona fluorescens. J. Plant Dis. Prot. 107: 514-527.

Nadlony, L. and Sequira, L. 1980. Increase in peroxidase activities are not directly involved in induced resistance in tobacco. Physiol. Plant Pathol. 16: 1-8.

Nambisan, B. 1994. Pathogenesis-related proteins in Cassava mosaic disease. In: Advances in Horticulture, (Eds.) Chadha, K. L. and Nayar, G. G., Vol.8. Malhotra Publishing house, New Delhi. pp. 375-379.

Porter, C.A. 1959. Biochemistry of plant virus infection. Adv. Virus Res., 6: 75-91.

Raghu, D., Senthil, N., Raveendran, M., Karthikayan, G., Pugalendhi, L., Nageswari, K. and Mohan, C. 2012. Molecular Studies on the Transmission of Indian Cassava Mosaic Virus (ICMV) and Sri Lankan Cassava Mosaic Virus (SLCMV) in Cassava by Bemisia tabaci and Cloning of ICMV and SLCMV Replicase Gene from Cassava. Mol. Biotechnol., DOI 
10.1007/s12033-012-9503-1.

Saravanakumar, D., Lavanya, N., vivekanandan, R., Loganathan, M., Ramanathan, A. and Samiyappan, R. 2003. PGPR mediated induced systemic resistance (ISR) in mubg bean against Macrophomina root rot disease. In: $6^{\text {th }}$ International Workshop on PGPR, Calicut, India, pp. 146-152.

Shannon, L.M. 1968. Plant Isoenzymes. Annual Review of Plant Physiol., 19: $187-210$.

Singh, R. and Srivastava, R.P. 1974. Studies on the rosette virus infected groundnut (Arachis hypogaea L.) III. Effect on carbohydrate and phosphorus metabolism. Acta Bot. Indica, 2: 33-36.

Sundaravadana, S. 2002. Management of black gram (Vigna mungo (L). Hepper) root rot (Macrophomona phaseolina (Tassi.) Goid. With bioagens and nutrients. Tamil Nadu Agricultural University, Coimbatore. M.Sc. Thesis.

Thankappan, M. and Chacko, C.I. 1976. Effect of cassava mosaic on the different plant parts and tuber yield in cassava. J. Root Crops, 2: 45-47.

Van Loon, L.C. 1997. Induced resistance in plants and the role of pathogenesis related proteins. Eur. J. Plant Pathol., 103: 753-765.

Van Loon, L.C., Bakker, P.A.H.M. and Pieterse, C.M.J. 1998. Systemic resistance induced by rhizosphere bacteria. Annu. Rev. Phytopathol., 36: 453-483.

Van Loon, L.C. and Callow, J.A. 1983. Transcription and translation in the diseased plant. In: Callow JA (ed), Biochemical Plant Pathology, John Wiley and Sons, Chichester. pp. 385414.

Vasanthi, V.J. 1998. Elimination of Indian Cassava mosaic virus (ICMV) in cassava (Manihot esculenta Crantz.) through meristem tip culture and study on the physiology of infected plants. M.Sc. Thesis, Tamil Nadu Agricultural University, Coimbatore, India. pp.119.

Vidhyasekaran, P. and Muthamilan, M. 1995. Development of formulations of Pseudomonas fluorescens for control of chickpea wilt. Plant Dis., 79: 782-786.

Witham, F.H., Blayder, D.F. and Devlin, R.M. 1971. Experiments in Plant Physiology, Van Nostrand New York. pp. 245.

Yedidia, I., Benhamou, N. and Chet, I. 1999. Induction of defense responses in cucumber plants (Cucumis sativus L.) by the biocontrol agent Trichoderma harzianum. Appl. Environ. Microbiol., 65: 1061-1070.

Zdor, R.E. and Anderson, A.J. 1992. Influence of root colonizing bacteria on the defense responses in bean. Plant Soil, 140: 99-107.

\section{How to cite this article:}

Raghu Duraisamy, Chandrasekar Arumugam, Senthil Natesan, Raveendran Muthurajan, Karthikeyan Gandhi, Pugalendhi Lakshmanan, Nageswari Karuppusamy, Mohan Chokkappan. 2017. Host-Pathogen Interaction of Cassava (Manihot esculenta Crantz) and Cassava Mosaic Viruses (ICMV and SLCMV). Int.J.Curr.Microbiol.App.Sci. 6(7): 1305-1317. doi: https://doi.org/10.20546/ijcmas.2017.607.157 